\title{
Quran and Sunnah Perspective on Informal Logical Fallacies
}

\author{
Mohammad Manzoor Malik
}

\begin{abstract}
This research is aimed at providing critical appraisal of some informal logical fallacies from the Quran and Sunnah. The fallacies are defined adequately, analyzed logically, understood conceptually, and then criticized from Islamic perspective based on the Quran and Sunnah. First some fallacies of relevance are undertaken. Argumentum ad Hominem (Argument Directed at the Person) according to Islamic perspective is valid in respect to transmitted knowledge (uloom naqliah); on the other hand, this fallacy is invalid in respect to rational knowledge (uloom aqliyah) in inclusion of empirical knowledge (uloom tajribiyah). Argumentum ad Populum (Appeal to the People) fallacy according to Islamic perspective is accepted as a valid fallacy if what someone, elite, or majority hold is against the evidences and facts. However, in terms of keeping law and order in a society, Islam encourages the concept of Shura (consultation and group decision) and jamaah (unity and group) to make it possible that among many good options, Muslims would be able to follow any one with majority agreement to get over any disagreement or conflict. Among fallacies of presumption, some fallacies were undertaken as follows. Secundum quid (Fallacy of Hasty Generalization) is accepted fallacy according to Islamic perspective. The Islamic spirit is against hasty generalizations. Argumentum ad Verecundiam (Argument from Authority) is an accepted fallacy according to Islamic perspective. Islam emphasizes on evidence and proof in accepting or negating any fact. This is primary. However, proper authorities should be consulted on matters, this is what the Quran and Sunnah encourages.
\end{abstract}

Key words: logic, fallacies, critical thinking, Quran, Sunnah, Islamization, reason.

Introduction: This research is aimed at providing an Islamic perspective on informal logical fallacies which is based on the Quran and Sunnah. Informal fallacies are under three classifications, of relevance, ambiguity, and presumption. However, only a few fallacies are undertaken here which are under relevance and presumption. The methods applied in this research are descriptive, analytical, conceptual, and critical. In the beginning, the background of the subject and basic concepts such as argument, fallacy, and critical thinking are precisely mentioned. Subsequently, the fallacies are defined, analyzed, and then appraised according to Islamic perspective by deriving on evidences from the Quran and Sunnah. 
Background: The contemporary era is an age of information; access to knowledge, information, facts, and opinions is in reach of general public and no means of censorship work effectively. Beside many benefits and advantages, the flux of information from conventional and electronic media comes with propaganda and deceit. Distortion and deception is widespread in media and the Internet. Despite of that, people still need measures to enable them to cope with the challenges that result from all types of media. One of the measures is that people and particularly students should be equipped with critical aptitude thus enabling them to discriminate and differentiate between facts and fiction and to detect faults in reasons and reasoning, in order to avoid getting misinformed, misdirected, and incorrectly persuaded.

There are many reasons for which fallacies are committed. One of these reasons is committing fallacies by deliberate intent, deliberately utilizing fallacious arguments to pursue others for personal gain. Some examples are as follows: "politicians want your vote; dictators want to exploit your passions and prejudices; advertisers want you to purchase their product; ...; and fanatics or zealots (religious, political, nationalistic, etc.) want you to join them". The other reason is careless intellectual habits, it includes: "mental laziness, emotional disposition, uncritical reasoning habits, one's worldview (German: weltanshaunng)". ${ }^{1}$

The above subject matter falls under the academic discipline which has become known in academia as "critical thinking", which is "the process of identifying, explaining, and evaluating beliefs". ${ }^{2}$ Critical thinking "is the formation of logical inferences (Simon \& Kaplan, 1989), the development of cohesive and logical reasoning patterns (Stahl \& Stahl, 1991), and careful and deliberate determination of whether to accept, reject, or suspend judgment (Moore \& Parker, 1994)" ${ }^{3}$. Halpern himself defined critical thinking as "... the use of cognitive skills or strategies that increase the probability of a desirable outcome". ${ }^{4}$ Rick D. Rudd holds that some clarity in

1“Logic Informal Fallacies" Paul Leclerc , last modified February 26, 2004, http://faculty.ccri.edu/paleclerc/logic/fallacies.shtml.

2 Ryan Wasserman, Arguments, Western Washington University, Accessed February 28, 2014. myweb.facstaff.wwu.edu/wasserr/114/Arguments.pdf. 24.

3 Diane F. Halpern, Critical Thinking across the Curriculum: A Brief Edition of Thought and Knowledge (Mahwah, NJ: Lawrence Erlbaum Associates, 1997), 4.

${ }^{4}$ Diane F. Halpern, Critical Thinking across the Curriculum: A Brief Edition of Thought and Knowledge (Mahwah, NJ: Lawrence Erlbaum Associates, 1997), 4. 
defining critical thinking was achieved when a group of leading researchers with expertise in the field was asked to define critical thinking through a Delphi study in 1990 (Facione). The researchers hypothesized that there is a set of intellectual virtues or habits of mind that reflect one's disposition to think critically. These virtues are identified in the Delphi consensus statement:

"The ideal critical thinker is habitually inquisitive, well-informed, trustful of reason, open-minded, flexible, fair-minded in evaluation, honest in facing personal biases, prudent in making judgements, willing to reconsider, clear about issues, orderly in complex matters, diligent in seeking relevant information, reasonable in the selection of criteria, focused in inquiry, and persistent in seeking results which are as precise as the subject and the circumstances of inquiry permit." 5

One of the major areas which are part of critical thinking is to understand arguments, statements, claims, and opinions. Most of the conversation we do is meant to make arguments. The education system, political discourse, religious sermons, marketing and sales, to name a few, are actually about making arguments. These arguments can be sometimes faulty and misleading. One has to remain on guard to make sure he/she is not lead into deception. To understand these faults and errors in arguments a huge collection of analysis has produced a number of fallacies. Arguments made by a person are judged in two ways: by checking the correctness of the facts stated in the propositions (premises) of the arguments (validity) and correctness of the relation between those facts (inference) in making a right conclusion from them (soundness). In short, "An argument is valid if it would be contradictory to have the premises all true and conclusion false. An argument is sound if it's valid and has every premise true". 6

Logical Fallacies: The word "fallacy" is error in reasoning; it may derive from the Latin word fallere meaning, "to deceive, to trip, to lead into error or to trick." The word may also derive

${ }^{5}$ Rick D. Rudd, "Defining Critical Thinking," Techniques, October 2007.

${ }^{66}$ 1. Harry J. Gensler, Introduction to Logic (London: Routledge, 2002), 4. 
from the Greek phelos, meaning "deceitful."7 Fallacies are two types: formal and material. The formal fallacy is due to the structure of the reasoning process; the material fallacy is due to the thought which underlies the structure. ${ }^{8}$ In other words, "a fallacy is a bad argument that is psychologically persuasive." Therefore, fallacies are flaws in arguments that prevent "the argument from being either valid (if the argument is a deductive argument) or strong (if the argument is an inductive argument)." not depend on the logical form of that argument, and is instead traceable to the meanings of the non-logical expressions contained in the argument." 11 Therefore "a sizeable literature attests to the prevalence of the belief among philosophers and psychologists that informal reasoning commonly falls short of any ideal, and lengthy lists of ways in which reasoning goes astray suggest the existence of standards, even if incomplete and only implicit, in investigators' heads." 12

Informal fallacies could be said are illegitimate moves in arguing; "because they steer discourse away from rather than toward truth." 13 The discourse on informal fallacies is part of interest in Islamic works on dialectic. ${ }^{14}$

7 “Fallacies", Accessed February 28, 2014, www.sun-design.com/talitha/fallacies.htm.

8 John Grier Hibben, Logic, Deductive and Inductive (New York: Charles Scribner's Sons, 1905), 157.

9 Arguments, Ryan Wasserman, Western Washington University p.16 (online)

${ }^{10}$ Roy T. Cook, A Dictionary of Philosophical Logic (Edinburgh: Edinburgh University Press, 2009), 116.

11 Roy T. Cook, A Dictionary of Philosophical Logic (Edinburgh: Edinburgh University Press, 2009), 153.

12 James F. Voss, David N. Perkins, and Judith W. Segal, eds., Informal Reasoning and Education (Hillsdale, NJ: Lawrence Erlbaum Associates, 1991), 300.

13 Susan T. Gardner, Thinking Your Way to Freedom: A Guide to Owning Your Own Practical Reasoning (Philadelphia: Temple University Press, 2009), 76.

${ }^{14}$ Deborah L. Black, Logic in Islamic philosophy, 1998, Routledge, Accessed January 20, 2014, http://www.muslimphilosophy.com/ip/rep/H017. 
Islamization and Islamisation of Knowledge: The project of Islamization of knowledge, which is an active term to my understanding, means desecularization of knowledge thus purifying the human made knowledge from secular nature and, at the same time, laying foundation of knowledge on Islamic principles. The latest addition to this movement has been a novel contribution from Tan Sri Professor Muhammad Kamal Hassan, the former rector of the International Islamic university Malaysia, who proposed "Islamisation of Knowledge" which to my own understanding is a passive term, meaning types of knowledge which come from anywhere regardless of who created them, if correspond to Islam and fit in the Islamic paradigm of knowledge, then there should be no problem in incorporating that knowledge in Islamic syllabuses and curricula. The faculty of reason which human beings are gifted with is given to all human beings without any discrimination and human reason is able to find wisdom, create, and innovate. Therefore, as long as this wisdom is not against the clear and obvious truth of revealed knowledge there should be no problem in accepting it.

This above approach of Islamisation is very relevant to the subject of this research. The subject of logical fallacies is closely connected with logic. Logic is connected with reason. It's a grammar for reasoning or of reasoning. Beside many problems with reason is the problem how reason works. Are there any rules for it? This subject was well taken by Aristotle in Organon, a standard work on logic. The whole legacy from Aristotle came to be known as Greek logic. Once this logic ended in Muslims lands it created a debate. The most dominating subject among Muslims was actually about reason and revelation. All Muslim scholars accepted reason as a source of knowledge. However the famous discussion included debate on the primacy of reason and revelation, whether reason or revelation is primary. On this subject, Muslim philosophers and theologians remained divided. Logic remained contested between opponents and proponents. Ibn Tymiah wrote a refutation of Greek logic, showing inherent problems in it. Whereas, many Muslim scholars supported logic, Al-Gazali remained positive about it and used it in his book of the principles of jurisprudence.

However, whether there are rules for reason or not, it is itself a big subject. If there are no rules then it would be difficult to differentiate rationality from irrationality. Of course, smart from stupid. And if there are rules, then what are those rules? Ibn Tymiyah and those who refuted logic to my own understanding developed "deconstruction" of logic as an 
epistemological issue, without giving any equally alternative substitute. Whereas, a deep look into the Quran and Sunnah will help a scholar to come up with a framework for reasoning. Certain fundamental rules are also possible. The scope of deciphering such rules and foundations in the Quran and Sunnah which could provide bedrock for Islamic logic is of high scope. Yet, the logic which is developed in the Western philosophy has many positive things which could be adopted, that is why Al-Gazali like scholar appreciated the benefits of logic and so did many traditional ulama who adopted it in their madrasah curriculum such as in India. Remaining within the confines of this research, the researcher believes that many logical fallacies which are highlighted by Western scholarship are consistent with Islamic stance and by the virtue of holding "Islamisation of Knowledge" position there is no problem in incorporating these fallacies into Islamic curriculum in the areas of critical study, logic, reasoning and polemics.

Taxonomy of Informal Fallacies: Once it has been decided what is to count as a logical fallacy, the question remains as to how the various fallacies are to be categorized. "Fallacies of relevance, presumption, and ambiguity are quite standard". ${ }^{15}$

Fallacies of Relevance: The development of the concept of relevance historically has its roots in Greek logic and rhetoric. Since the time of Aristotle the fallacy of irrelevance has been part of logic books. It has been so throughout ages. However "the most important source of material on how relevance is part of argumentation comes from Greek rhetorical manuals". ${ }^{16}$ An argument is made of premises, and conclusions follow from these premises. The fallacy of relevance shows the irrelevance of premises to the conclusion. In other words, premises may be relevant to the conclusion emotionally or psychologically, but not logically. In more precise manner, "In fallacies of relevance the premises are logically irrelevant to the conclusion. However, they are psychologically or emotionally relevant to the conclusion. Therefore, the conclusion appears or seems to follow from the premises although the premises in fact provide

15 “Logic Informal Fallacies” Paul Leclerc, last modified February 26, 2004, http://faculty.ccri.edu/paleclerc/logic/fallacies.shtml.

${ }^{16}$ Douglas Walton, Relevance in Argumentation (Mahwah, NJ: Lawrence Erlbaum Associates, 2004), xi. 
no genuine evidence for the conclusion". ${ }^{17}$ Therefore, the task is to distinguish between genuine evidence from emotional appeal. To study relevance "one of the best entry points to studying relevance is through irrelevance, because objections on the basis of irrelevance in argumentation are, in some instances fairly clear and pointed, in specifying what is objectionable." 18

\section{Argumentum ad Hominem (Argument Directed At The Person)}

Argumentum ad Hominem is also known as "personal abuse, personal attacks, abusive fallacy, damning the source, name calling, needling [form of], refutation by character)". ${ }^{19}$ This argument revolves around "the person" who makes a statement of knowledge, or makes a claim or opinion. Instead of subjecting that claim or statement, etc to any epistemological scrutiny, it is rather accepted or rejected because of the person's personality. The use of this fallacy is widespread. ${ }^{20}$ The Oxford Dictionary of Philosophy gives the following succinct definition of Argumentum ad Hominem:

ad hominem: attempting to disprove what a person holds by attacking the person (less commonly, supporting a person's contention by praising the person), or, more generally, arguing in a way that may or may not be forceful against a particular person's position, but does not advance matters for those who do not hold that person's particular combination of beliefs. $^{21}$

Informal Structure of ad Hominem is as follows:

17 “Logic Informal Fallacies” Paul Leclerc, last modified February 26, 2004, http://faculty.ccri.edu/paleclerc/logic/fallacies.shtml.

${ }^{18}$ Douglas Walton, Relevance in Argumentation (Mahwah, NJ: Lawrence Erlbaum Associates, 2004), xi.

${ }^{19}$ Bo Bennett, Ad Hominem (Abusive), Archieboy Holdings, LLC., last modified 2013, http://www.logicallyfallacious.com/index.php/logical-fallacies/10-ad-hominem-abusive.

${ }^{20}$ Yvonne Raley, "Character Attacks: How to Properly Apply the Ad Hominem”, Scientific American, June/July 2008, accessed May 22, 2008, http://www.scientificamerican.com/article/character-attack/.

21 Simon Blackburn, The Oxford Dictionary of Philosophy (Oxford: Oxford University Press, 1996), 24. 


\section{Person $\boldsymbol{L}$ says argument $\boldsymbol{A}$.}

Person $\boldsymbol{L}$ 's circumstance or character is not satisfactory.

Argument $\boldsymbol{A}$ is not a good argument. ${ }^{22}$

This fallacy as described above is widespread in sorts of discourses be that about religion, history, politics, or social issues. This fallacy needs to be addressed from Islamic perspective, seeing how Islam considers this fallacy.

In Islamic tradition there is a distinction between transmitted knowledge (uloom naqliah) and rational knowledge (uloom aqliyah). The transmitted knowledge includes the knowledge that has passed over by generations by narration (rivayah), and rational knowledge in broader sense includes both intellectual or rational (uloom aqliyah) and empirical knowledge (uloom tajribiyah).

The transmitted knowledge in Islamic tradition includes basically the narrations of the Prophet Mohammad (PBUH). The narrations of the Messenger are also called Hadith. The narration has two parts namely, chain of narrators (sanad) and the text (matan). The scholars of hadith have set rules for accepting and rejecting hadith; these rules are written in the books of the principles of hadith (usool-al-hadith). Among conditions of accepting any report, the narrator should be reliable. The most important qualities of a reliable narrator include: he should have meet the person preceding him, honest, trustworthy, has a good memory. ${ }^{23}$ Here, a hadith could get rejected or would not be treated of high authority if these qualities are diminished. That is why there is a collection of hadith which is categorized as fabrications by Hadith scholars because of the persons who have narrated them were found unreliable. Why Islamic tradition is strict in this matter is because the Prophetic traditions are part of religion. In this regard, Imam Muslim mentions the report of Muhammad Ibn Sirin who said: In the beginning there were no questions regarding the chain of narrator (sanad) but when the tribulation (fitnah) occurred people start asking about narrators, so those who were among beholders of Sunnah, their narrations were accepted, whereas those who held innovations (bidah), their narrations were

22 "Introduction to Logic", Licensed under the GFDL, accessed February 28, 2014, http://philosophy.lander.edu/logic/person.html.

${ }^{23}$ Ibn Hajar, Nukhbat al-fikar fi mușțalah Hadìth ahl al-athar, (Beirut: Dar al-Diyan lil-Turath, 1988). 
rejected. ${ }^{24}$ Furthermore, Imam Muslim reported Muhammad Ibn Sirin saying, the knowledge of Hadith is religion, therefore you should know from who you are taking (learning) it. ${ }^{25}$ However, the Quran had already set a rule on accepting or rejecting reports, the Quran states, "O ye who believe! If a wicked person comes to you with any news, ascertain the truth, lest ye harm people unwittingly, and afterwards become full of repentance for what ye have done." 26 This verse includes all kinds of reports. Therefore, Islam cautions on who to take report from and who not to. Therefore, religious knowledge which is in the form of narrations and historical accounts are to be taken seriously by verifying their sources and reporters.

The other type of knowledge is rational, intellectual, and scientific. This knowledge that could be verified without the person, who reports it, does not need any verification and investigation of the person. Islam encourages using intellect, senses, and evidences in understanding. The Quran stresses on providing good arguments and evidences in case of proposing a position or disagreement. The Quran challenges the people of the book by stating, "And they say: "None shall enter Paradise unless he be a Jew or a Christian." Those are their (vain) desires. Say: "Produce your proof if ye are truthful." 27 The Quran says, "Lo! the worst of beasts in Allah's sight are the deaf, the dumb, who have no sense". ${ }^{28}$ On cosmology, the Quran states, "Or, Who originates creation, then repeats it, and who gives you sustenance from heaven and earth? (Can there be another) god besides Allah? Say, "Bring forth your argument, if ye are telling the truth!"29 And on obstructing the sense, "Many are the Jinns and men we have made for Hell: They have hearts wherewith they understand not, eyes wherewith they see not, and ears wherewith they hear not. They are like cattle, - nay more misguided: for they are heedless (of warning)". 30

\footnotetext{
24. Muslim Ibn Al-Hajjaj, Sahih Muslim, (Beirut: Dar Ihya At-Turath al-Arabi).

${ }^{25}$ Muslim Ibn Al-Hajjaj, Sahih Muslim, (Beirut: Dar Ihya At-Turath al-Arabi).

${ }^{26}$ The Quran, 49:6.

27 The Quran, 2:111.

28 The Quran, 8:22.

${ }^{29}$ The Quran, 27:64.

30 The Quran, 7:179.
} 
In conclusion, the fallacy of Argumentum ad Hominem is regarded in Islamic tradition only when historical reports and narrations are rejected because of the unreliability and known vices of a person as being a liar, untrustworthy, having a sectarian bias, and dishonest. As far as the understanding of religion is concerned, this fallacy also does not affect in accepting or respecting the opinion as far as the opinion is backed by good evidences and arguments. In the same manner if a reliable person gives account on any subject his evidences also are in need of verification. Being pious does not guarantee soundness of an argument. However, the followers of religion should follow pious scholars regarding the opinions on religious matters as a caution they are not mislead. But after scrutiny, this condition only applies to those who do not have enough capacity to understand and think or weight the worth of any argument or opinion. For those, who are able and have intellectual capacity and can understand the issues of religion, this condition does not apply. Regarding rational and empirical knowledge, Muslims are encouraged to learn from everyone regardless of their faith and character. Therefore, this fallacy does not apply to any discourse from Islamic perspective that is actually based on accepted evidences, data, and methods.

\section{Argumentum ad Populum (Appeal to the People)}

This argument means popular appeal or appeal to the majority; it appeals "to the prejudices of the people.' ${ }^{31}$ It is "the fallacy of attempting to win popular assent to a conclusion by arousing the feeling and enthusiasms of the multitude". ${ }^{32}$ Avery detailed description of this fallacy is given by Simon Blackburn as follows:

Argumentum ad populum is the use of appeal to popular opinion to support a conclusion. It may take the form of appeal to group loyalties, popular trends of one kind or another, or to customary ways of doing things. This type of argumentation is reasonable in many cases, but it can be used as a sophistical tactic to bring pressure against an opponent in

\footnotetext{
${ }^{31}$ Simon Blackburn, The Oxford Dictionary of Philosophy (Oxford: Oxford University Press, 1996), 24.

32 "Introduction to Logic", Licensed under the GFDL, accessed February 28, 2014, http://philosophy.lander.edu/logic/person.html.
} 
argument, or to appeal to group interests or loyalties in an emotional way, in lieu of presenting stronger forms of evidence that should be provided. ${ }^{33}$

Most, many, or all persons believe statement $\mathbf{p}$ is true.

Statement $\mathbf{p}$ is true. ${ }^{34}$

Islam supports truth. The metaphysical truth is revealed in the revelation. The truths which are not revealed, Islamic epistemological guidelines stresses on methods of certainty, discourages guessing and conjecture. The Quran states, "And pursue not that of which thou hast no knowledge; for every act of hearing, or of seeing or of (feeling in) the heart will be enquired into (on the Day of Reckoning)". ${ }^{35}$ The Quran states, "O ye who believe! Avoid suspicion as much (as possible): for suspicion in some cases is a sin: And spy not on each other behind their backs. Would any of you like to eat the flesh of his dead brother? Nay, ye would abhor it...But fear Allah: For Allah is Oft-Returning, Most Merciful". ${ }^{36}$ Regarding historical facts, the Quran states, "That they said (in boast), "We killed Christ Jesus the son of Mary, the Messenger of Allah";- but they killed him not, nor crucified him, but so it was made to appear to them, and those who differ therein are full of doubts, with no (certain) knowledge, but only conjecture to follow, for of a surety they killed him not" ${ }^{37}$ Regarding the majority opinion of the people, the Quran states, "Wert thou to follow the common run of those on earth, they will lead thee away from the way of God. They follow nothing but conjecture: they do nothing but lie". ${ }^{38}$ Because, guessing is not equal to the truth, the Quran states, "But most of them follow nothing but fancy: truly fancy can be of no avail against truth. Verily Allah is well aware of all that they do". ${ }^{39}$ Regarding false divinities, the Quran states, "If not Him, ye worship nothing but names which ye have named, - ye and your fathers,- for which Allah hath sent down no authority: the command

33 Ted Honderich, ed., The Oxford Companion to Philosophy (Oxford: Oxford University Press, 1995), 49.

34 "Introduction to Logic", Licensed under the GFDL, accessed February 28, 2014, http://philosophy.lander.edu/logic/person.html.

35 The Quran, 17:36.

36 The Quran, 49: 12.

${ }^{37}$ The Quran, 4:157.

38 The Quran, 6:116.

39 The Quran, 10:36. 
is for none but Allah: He hath commanded that ye worship none but Him: that is the right religion, but most men understand not..."40

In these verses "conjecture" and its evils have been criticized and this conjecture can be sometimes property of a group, elite, or a single person who may have greater authority and influence. Looking at many evidences from the Quran it becomes clear any position held by whosoever should be based on clear evidences, be that a single person, elite, or majority. Regarding the inherited customs and believes, the Quran states, “

When it is said to them: "Follow what Allah hath revealed:" They say: "Nay! we shall follow the ways of our fathers." What! even though their fathers Were void of wisdom and guidance?"41; "When it is said to them: "Come to what Allah hath revealed; come to the Messenger": They say: "Enough for us are the ways we found our fathers following." what! even though their fathers were void of knowledge and guidance?"42

In short, it's the truth which a Muslim is supposed to follow. Majority of the people, a group, or a single authority can be wrong in their understanding. However, in terms of keeping law and order in a society, Islam encourages the concept of Shura (consultation and group decision) and jamaah (unity and group) to make it possible that among many good options, Muslims would be able to follow any one with majority agreement to get over any disagreement or conflict.

Fallacies of Presumption: Fallacies of presumption are not logical errors; they are rather misusing the facts. They begin with a false or unwarranted assumption and therefore fail to support the conclusion. "The fallacy of presumption may occur when something is assumed to be true though it is not reasonable to accept it in the relevant context". ${ }^{43}$ Presumptive inference "is the basis of kinds of argumentation that are very common in everyday arguments like the

\footnotetext{
40 The Quran, 12: 40.

41 The Quran, 2:170.

42 The Quran, 5:104.

43"Different forms of the Fallacies of Presumption explained with examples" accessed February 28, 2014, http://www.preservearticles.com/201106017371/different-forms-of-the-fallacies-ofpresumption-explained-with-examples.html
} 
argument from sign, the argument from consequences, and the appeal to expert opinion in argument". 44

\section{Secundum quid (Fallacy of Hasty Generalization)}

This fallacy is also known as: "argument from small numbers, statistics of small numbers, insufficient statistics, unrepresentative sample [form of], argument by generalization, faulty generalization, hasty conclusion [form of], inductive generalization, insufficient sample, lonely fact fallacy, over generality, over generalization". ${ }^{45}$ Hasty generalization is jumping to conclusions. It is also poisoning the well; it is "the informal fallacy that occurs when one draws a general conclusion from a sample that is too small, biased, or otherwise unrepresentative" ${ }^{46}$

The logical form of the argument is as follows:

Sample $\mathbf{S}$ is taken from population $\mathbf{P}$.

Sample $\mathbf{S}$ is a very small part of population $\mathbf{P}$.

Conclusion $\mathbf{C}$ is drawn from sample $\mathbf{S} .^{47}$

Generalizations, stereotypes, and racial profiling are problems that loom over many discourses. The Islamic spirit is against hasty generalizations. The best example which could be cited from the Quran is how Allah speaks about the people of the book (ahlulkitab). The Quran states, "Among the people of the Scripture (Jews and Christians) is he who, if entrusted with a Cantar (a great amount of wealth, etc.), will readily pay it back; and among them there is he who, if entrusted with a single silver coin, will not repay it unless you constantly stand demanding, because they say: "There is no blame on us to betray and take the properties of the illiterates

44 1. Douglas N. Walton, Argumentation Schemes for Presumptive Reasoning (Mahwah, NJ: Lawrence Erlbaum Associates, 1996), ix.

45 Bo Bennett, Hasty Generalization, Archieboy Holdings, LLC., last modified 2013, http://www.logicallyfallacious.com/index.php/logical-fallacies/101-hasty-generalization

${ }^{46}$ Roy T. Cook, A Dictionary of Philosophical Logic (Edinburgh: Edinburgh University Press, 2009), 135.

${ }^{47}$ Bo Bennett, Logically Fallacious, Archieboy Holdings, LLC., last modified 2013, http://www.logicallyfallacious.com/index.php/logical-fallacies/101-hasty-generalization 
(Arabs)." But they tell a lie against Allah while they know it." ${ }^{\text {"48 }}$ Even about prohibited things Allah mentions their qualities for example "They ask you about intoxicants and gambling: say, "In them there is a gross "ithm" (sin), and some benefits for the people. But their sinfulness far outweighs their benefit." 49

\section{Argumentum ad Verecundiam (Argument from Authority)}

This fallacy is also known as: "argument from authority, appeal to false authority, argument from false authority, ipse dixit, testimonials [form of]". 50 "Argumentum ad Verecundiam: (argument from authority) the fallacy of appealing to the testimony of an authority outside his special field. Anyone can give opinions or advice; the fallacy only occurs when the reason for assenting to the conclusion is based on following the recommendation or advice of an improper authority". ${ }^{51}$

The Dictionary of Philosophy briefs the definition as follows:

Argumentum ad verecundiam: An argument availing itself of human respect for great men, ancient customs, recognized institutions, and authority in general, in order to strengthen one's point or to produce an illusion of proof. ${ }^{52}$

\section{Logical Form:}

According to person $\mathbf{1}, \mathbf{Y}$ is true.

Therefore, $\mathbf{Y}$ is true. ${ }^{53}$

\footnotetext{
${ }^{48}$ The Quran, 3:75.

${ }^{49}$ The Quran, 2:219.

${ }^{50}$ Bo Bennett, Logically Fallacious, Archieboy Holdings, LLC., last modified 2013, http://www.logicallyfallacious.com/index.php/logical-fallacies/21-appeal-to-authority. 51 "Introduction to Logic", Licensed under the GFDL, accessed February 28, 2014, http://philosophy.lander.edu/logic/person.html.

${ }^{52}$ Dagobert D. Runes, ed., The Dictionary of Philosophy, 4th ed. (New York: Philosophical Library, 1942), 19.

${ }^{53}$ Bo Bennett, Logically Fallacious, Archieboy Holdings, LLC., last modified 2013, http://www.logicallyfallacious.com/index.php/logical-fallacies/21-appeal-to-authority.
} 
Islamic spirit emphasizes on evidence and proof in accepting or negating any fact. The statements and arguments of knowledge should be based on clear evidences, sound reason, and proper use of senses. Islam also accepts a person may not be able to give advice on every matter and issue; people have different interests and expertise on different matters. This can be very well understood from the tradition of the Prophet (PBUH) which is as follows: Muslim narrates this story from different Companion. These are the three narrations which help us to understand the whole story: Talhah b. Ubayd Allah narrates that "I was with Allah's Messenger (peace be upon him) when we passed by some people who were tending the tops of their date palms. He asked: "What are these people doing?" (Some people) replied: "They are pollinating the trees by bringing the male parts into contact with the female parts." Allah's Messenger (peace be upon him) said: "I do not think that this brings any benefit." They were informed of this and abandoned the practice. Then Allah's Messenger (peace be upon him) was informed of their abandoning it and said: "If that will benefit them, then they should practice it. Indeed I only ventured a thought. Do not hold me account to what I think. However, when I speak to you about anything regarding Allah, then accept it, for indeed I never speak falsely about Allah the Almighty." 54 The second tradition is narrated from Râfi $b$. Khurayj who said that, "The Prophet (peace be upon him) had come to Madînah while they were cross-pollinating their date palms. He asked: "What are these people doing?" They replied: "This is something that has been our practice." He said: "Maybe if you were not to do so, it would be good." So they abandoned it and the crop that resulted was impoverished. They mentioned this to him and he said: "I am only a human being. When I command you with something regarding your religion, accept it. When I command you with something from my own opinion, then I am only a human being." Ikrimah (one of the hadith's narrators) said: "He said that or something to that effect." 55 The third tradition is narrated from Anas who said, "The Prophet (peace be upon him) passed by some people who were busy with pollination and said: "If they would not do this, then it would still come out right." The date crop that resulted was of a very poor quality. Then he passed by them and asked: "What is with your date palms?" They said: "You had told us such-and-such..." He said: "You know best the affairs of your worldly life." 56

54 Muslim Ibn Al-Hajjaj, Sahih Muslim, (Beirut: Dar Ihya At-Turath al-Arabi).

55 Muslim Ibn Al-Hajjaj, Sahih Muslim, (Beirut: Dar Ihya At-Turath al-Arabi).

56 Muslim Ibn Al-Hajjaj, Sahih Muslim, (Beirut: Dar Ihya At-Turath al-Arabi). 
Regarding knowledge and understanding, one if does not know should turn to those who know. In this case the authority should be expert and relevant, the Quran states, "So ask the people of knowledge if you know not". 57 "When there comes to them some matter touching (public) safety or fear, they divulge it. If they had only referred it to the Messenger or to those charged with authority among them, the proper investigators would have tested it from them (direct). Were it not for the Grace and Mercy of Allah unto you, all but a few of you would have followed Satan". 58

Regarding religious knowledge, a person should follow proper authorities that are called uoolul amar however in times of disputation, one should return to the primary sources of religion. The Quran states, "O ye who believe! Obey Allah, and obey the Messenger, and those charged with authority among you. If ye differ in anything among yourselves, refer it to Allah and His Messenger, if ye do believe in Allah and the Last Day: That is best, and most suitable for final determination". 59

Conclusion: This research was aimed at providing critical appraisal of informal logical fallacies from Islamic perspective. In this research some fallacies under categories of relevance, ambiguity, and presumption were studied. They were defined adequately, analyzed logically, properly understood conceptually, and then criticized from Islamic perspective respectively.

First some fallacies of relevance were undertaken. They are in order as follows. Argumentum ad Hominem according to Islamic perspective is valid in respect to transmitted knowledge (uloom naqliah) such as Hadith narrations and historical accounts. On the other hand, this fallacy is invalid in respect to rational knowledge (uloom aqliyah) in inclusion of empirical knowledge (uloom tajribiyah). Argu mentum ad Baculum is valid according to Islamic perspective when matters are concerned with faith and the creed with condition that such applies to only believers because of having epistemic assurance by the belief system. On the other hand, this fallacy is invalid regarding non-believers, because Islam is not meant to be forced on others. Furthermore, rest of the statements which do not come under surest revealed knowledge, this fallacy is accepted as valid. Because, Islam stresses on truth and what is not truth should not be

\footnotetext{
57 The Quran, 16:43.

58 The Quran, 5:83.

${ }^{59}$ The Quran, 4:59.
} 
accepted if forced on people. Argumentum ad Populum fallacy according to Islamic perspective is accepted as a valid fallacy if what someone, elite, or majority hold what is against the evidences and facts. However, in terms of keeping law and order in a society, Islam encourages the concept of Shura (consultation and group decision) and jamaah (unity and group) to make it possible that among many good options, Muslims would be able to follow any one with majority agreement to get over any disagreement or conflict. Among fallacies of presumption, some fallacies were undertaken as follows. Secundum quid is accepted fallacy according to Islamic perspective. The Islamic spirit is against hasty generalizations. Argumentum ad Verecundiam is an accepted fallacy according to Islamic perspective. Islamic spirit emphasizes on evidence and proof in accepting or negating any fact. This is primary. However, proper authorities should be consulted on matters, this is what the Quran and Sunnah encourages. 